\title{
The Impact Analysis Of Stock Reminder Of Goods To Quality Company
}

\author{
Anita Bawaiqki Wandanaya ${ }^{1}$, Dea Rahmasary ${ }^{2}$ \\ ${ }^{1,2}$ Raharja University, JL. Jendral Sudirman No.40 Modern Cikokol Tangerang \\ e-mail: anita@raharia.info, dea.rahma@raharia.info
}

\begin{abstract}
In the development of technology today especially on the needs of information in the business world becomes very important in determining the progress of a company. Where good activity in a company or technology is very determined by the information available. In an enterprise data collection system The current running goods are still using Microsoft Excel to log out and go in goods. The current system still has many shortcomings and disadvantages such as requiring a long time to know the quantity of goods stock because the warehouse admin has to calculate directly the amount of physical stock, the occurrence of the difference The number of goods request with the expenditure of goods due to error calculation by warehouse admin, it takes a long time to make the report of raw material request and expense, causing the company's performance and quality to be Hampered. Based on the problem, it needs a reminder to help the staff admin of the stock to manage the demand and expenditure of raw materials to avoid the difference in stock raw materials.
\end{abstract}

Keywords: Inventory, Company, Reminder.

\section{Introduction}

The development of information technology in this globalization era has progressed rapidly. So it can affect all aspects of life. This can be seen with the number of companies or business entities or agencies not separated from the influence of technology in its activities, especially computer technology makes a job more effective and efficient [1].

Good activity in a company or technology is also determined by the information available. In order to manage the available information technology Information that can properly organize the company data in a structured and easily understood [2]. A company or organization must have a primary goal of becoming advanced and thriving. An important key in advancing a company or organization is with a fast and precise information system.

This aims to keep the company in updating information system technology in the era of globalization as it is today [3]. Looking at the rapid development of technology, the company requires a reliable system in collecting, storing and processing data into useful information to make the job better [4].

The current raw material inventory logging system still has a few that use Microsoft Excel to log out and go raw materials. The current running system still has many shortcomings and weaknesses such as it takes a long time to know the amount of stock of goods raw material because the warehouse admin should calculate directly the amount of physical stock, occurrence Difference in the amount of raw material demand with raw material expenditure due to error calculation by warehouse admin [5], it takes a long time to make the report of raw material request and expense causing company's performance Be hampered, the absence of a Reminder to remind the admin of the warehouse about the amount of raw material stock so that when raw materials are needed by the admin does not exist. 


\section{Research Method}

In a management process of scientific writing, research methods are needed in order to achieve goals and obtain accurate and reliable information, then needed by the author to perform several stages in the research.

\subsection{Analysis technique}

Using 4 (four) techniques in data analysis in this study, namely:

1. Can not provide reminder information stock of goods to be exhausted, \& expired goods

2. Requires a lot of bookkeeping to record every transaction that runs.

3. It takes a long time to generate a report because it must be created from scratch and is changed into the report format.

4. Frequent errors in the generation of reports.

\subsection{Literatur Review}

This paper uses the literature review method, to look for the theoretical basis of previous studies [6] which can be used for problem management. This method is used to gather information and data from multiple sources (literature), books, and journals for literature relevant to the needs of the writing of this paper [7]. There are 10 (ten) literature reviews that are used, there are:

1. Bibit Sudarsono, DKK (2017) under the title "Perancangan Program Sistem Informasi Persediaan dan Penjualan Barang Pada Toko Sparepart Motor". This research produces the program of inventory and sales of computerized goods that facilitate the process of grouping and searching the necessary data and facilitate controlling the stock of goods so that it can reduce the risk Errors in recording or calculation of transactions occurring. [8]

2. Research conducted by Paul R Dexter, and Susan Perkins in 2001 with the title " $A$ Computerized Reminder System To Increase The Use Of Preventive Care For Hospitalized Patients". The results of this trial provide compelling evidence that computerized reminders can increase the delivery of preventive care to hospitalized patients. The use of computerized reminders resulted in absolute ordering rates for both eligible patients and all hospitalized patients that were significantly higher than the rates in the control group.[9]

3. Research conducted by Prima Eka Syam Putri, Fachruddin, and Pareza Alam Jusia in the year 2014 with the title "Perancangan Aplikasi Perpustakaan Berbasis SMS Gateway (Studi Kasus : SMA Negeri 2 Kota Jambi)". The design method uses Unified Modeling Language (UML), the Visual Studio 2008 programming language. The final result in this library application makes it easier to process information about member data, book data, lending data, and book return data. [10]

4. Research conducted by Findra Kartika Sari Dewi, Theresia Devi Indriasari, and Yoris Prayogo in the year 2016 titled "Rancang Bangun Aplikasi Pengingat Kegiatan Akademik Berbasis Mobile". Design a reminder application using a database and use the development tools of the use case diagram, Physical Data Model, and CGM server. This research has successfully designed the schedule reminder application of academic activities in UAJY with the reliability of functions in accordance with expectations, and has an easy to use informative interface and beneficial for lecturers, students and TU. [11]

5. The research was conducted by Kosidin, and Resha Nur Farizah in 2016 under the title "Pemodelan Aplikasi Mobile Reminder Berbasis Android". The design method uses Unified Modeling Language (UML) and uses the Eclipse software development method, as well as using the Android Software Development Kit Manager development tool. The results of the implementation of the reminder application can be used by the user after the test phase process has been successfully done as expected. And once applied then the application is done evaluation of users using questionnaires.[12] 
6. The research was conducted by Dwi Ana Ratna Wati, Yuli Agusti Rochman in the year 2013, titled Model Penjadwalan Matakuliah Secara Otomatis Berbasis Algoritma Particle Swarm Optimization (PSO). This research focuses on designing the model of courses scheduling system is a routine work that every educational institution always do at the beginning of semester. The scheduling is a complex job because scheduling issues are combinatorial issues that have constraints to be met. These limits are divided into absolute limitations that must be met such as classroom availability and their capacity, lecturer availability, as well as students and soft restrictions such as lecturer preferences in selecting teaching time. This automatic scheduling Model aims to generate a schedule that meets all absolute limitations and minimizes total activation of soft limits in the form of Lecturer preferences. This process is done for each course that will be scheduled, so that a full schedule is obtained. Based on the results of the experiment, the PSO algorithm-based course scheduling model can perform scheduling tasks automatically and produce solutions that meet all the absolute limitations and minimize the activation of soft restrictions. By using the PSO-based scheduling model, the scheduling process is becoming faster than the manual scheduling process.[13]

7. The research conducted by Husnil Kamil in 2013 entitled Pengembangan Aplikasi Distribusi Surat Di Fakultas Teknologi Informasi Dengan Notifikasi SMS Menggunakan Framework YII dan Gammu. This research on the system of incoming mail management in the Faculty of Information technology is still done manually. This manual management poses several problems. Such issues include unmanaged archives, letters late until, letters not received with the recipient's supposed and damaged mail during distribution. A software is required to manage and distribute the outstanding mail in the Faculty of Information technology. Mail distribution applications in the Faculty of Information technology were developed using the YII framework to process Web-based application development and Gammu to add SMS Gateway features. Using the framework aims to accelerate the application development process. The mail distribution application also comes with a commenting feature that allows users to interact with other users. This research resulted in an application that can be used to manage and distribute mail at the Faculty of Information technology. Information technology but this application has fulfilled the basic functions of mail distribution application in the Faculty of Information technology..[14]

8. The research was conducted by Andre M. R. Wajong in the year 2015 titled "Applying Performance Dashboard in Hospitals". The performance of the dashboard is one way to improve the performance of the company, a hospital in this study, because of the ease it provides to the hospital's executive entity in measuring, supervising, and evaluating home performance are sick based on Key Performance indicators (KPIS). The information taken by the executive entity in making strategic decisions involves many separate data sources. By implementing the performance dashboard, existing data sources will be consolidated and demonstrated in informative visual form via the interface screen so that executives can easily understand and analyse the data.[15]

9. Research conducted by Shana Clor-Proell, Ryan Guggen mosdan Kristina M. Rennekamp in 2017 titled Mobile Devices and Investment Apps: The Effects of Push Notification, Information Release, and The Fear of Missing Out. This study discusses mobile technology has resulted in changes in how users receive financial information. That is, media is increasingly "describing " content into smaller pieces to accommodate mobile users, and mobile apps use push notifications to highlight this content. In addition, mobile devices have improved the user's ability to access investment information in real time. We check how this change and the investor's fear of "losing" investment information available (I-FoMO) affects the assessment of non-professional investors. Since some investors may experience this fear more than others, we develop a scale to measure the nature of these personalities and examine how I-FoMO affects investor reaction to mobile technology features. We found that push notifications have a greater impact on investor assessments when combined with non- 
shared, non-bundled content. Furthermore, we find that these results apply to high I-FoMO investors, but not low. Thus, the feature of mobile technology is likely to have a greater impact on those who have a tendency to fear of losing investment information. Our results have implications for investors, regulators, and researchers.[16]

10. The research conducted by Rachman Mulyandi and Cynthia Ayu Wulan Dini in 2014 entitled Aplikasi Absensi Pegawai Kecamatan Batuceper Tangerang Dalam Meningkatkan Akurasi Informasi. This explains about Batuceper Sub-district which is a government agency whose attendance system is still running manually. Where in the application of attendance system There are some things that are constraints. The obstacles that occur in terms of effectiveness, time efficiency and the process of absence. This form of attendance report is still a writing that can be difficult in the process of data retrieval, and the possibility of missing attendance data. With the above reasons the authors try to provide an alternative problem solving by creating an application attendance system that will record the list of employee attendance, arrival time, time of return, which will be made systematically and Computerized. This system eliminates the registration process of employees who are still running manually, that is by reducing the error rate by inputting the parent number of employees in the attendance process.[17]

From the 10 (ten) literature studies above, the author gained knowledge about the scope of research, starting from the method to the writing of research reports. But through this research, the author wants to explain the variety of studies that can be seen from several perspectives, which can be used as references or used in the management of other researchers' problems.

\section{Results and Analysis}

\subsection{Problem Analysis}

The problems faced from the running system is that it takes a long time to know the amount of raw material stock because the warehouse admin must calculate directly the amount of the physical stock, the difference in the number of requests Raw materials with raw material expenditure due to miscalculation by warehouse admins, takes a long time to make the report of raw material request and expense, causing company's performance to be hampered, absence of Reminder to remind the admin of the warehouse about the amount of raw material stock so that when the raw material needed does not exist, as well as the frequent delay of arrival of raw material stock listing materials [18].

\subsection{Use Case Diagram System}

A Use Case Diagram represents an interaction between an actor and a system. 


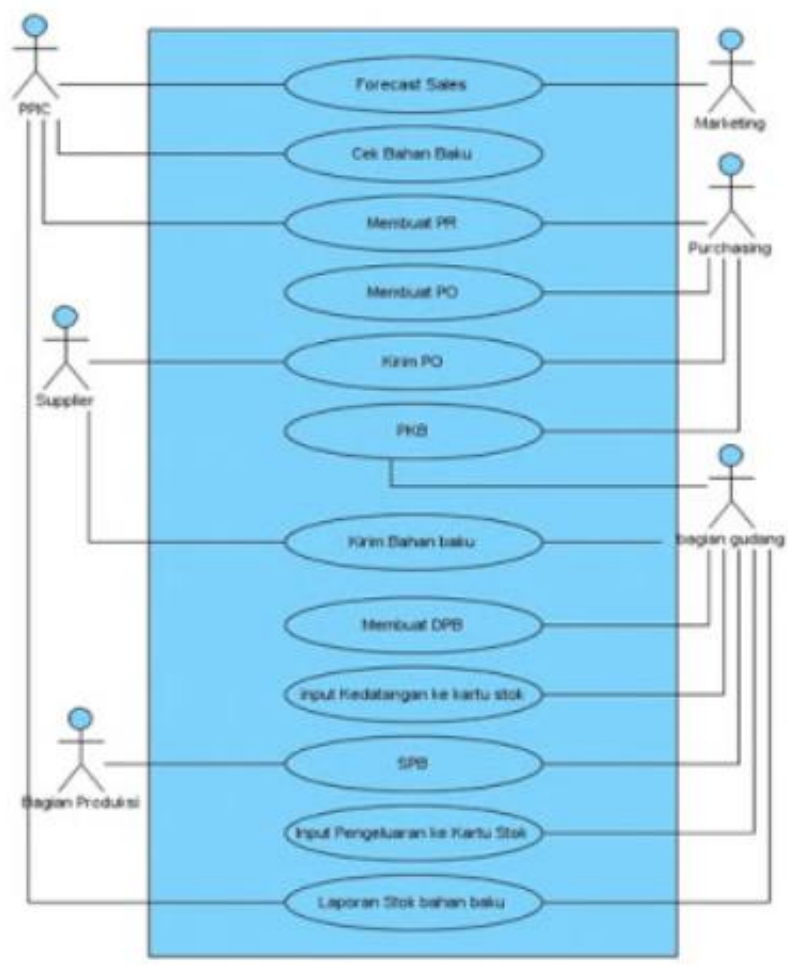

Figure 1. Use Case Diagram

Based on image 3.1. Use Case diagrams currently present:

1. 6 Actors who do activities include: Marketing Division, Section PPIC (Planing Product Inventory Control), Purchasing section, Supplier, warehouse parts and production parts.

2. 13 (thirteen) use case that can be done by these actors include:

1. Forecast Sales.

2. Check raw materials.

3. Create a PR (Purchase Requisition).

4. Create a PO (Purchase Order).

5. Send a PO.

6. Send PKB.

7. Send raw materials.

8. Make DPB.

9. Arrival Input to stock card.

10. Spb.

11. Provide raw materials.

12. Expense Input to stock card.

13. Raw Material Stock report.

\subsection{Needs Analysis System}

To overcome the constraints faced by the company, it can be advised alternative to problem solving by developing a system of information on basic material reminder of the web based supplies in hopes of assisting officers in the input and Can reduce mistakes or constraints that occur and facilitate decision making. The reminder information system should:

1. Can display an alert when the raw material stock in the warehouse is thinning. 
2. Can display reports and be printed in Microsoft Excel for data receipt and material expenditure from input results so that the officer does not need to regenerate again in the report generation.

3. Can add new data or change data, so that the system can be repaired immediately if there is an error in the input

\section{Conclusion}

Based on the results of the research done on the influence of stock reminder of goods to the quality of the company, research can draw conclusions as follows:

1. To overcome these constraints, a system that can give warning or notification when there is raw material that has been thinning so that the raw material is immediately ordered to the supplier.

2. Constraints that occur in the stock of goods that are running now there is a shortage of them require a long time to know the amount of inventory of goods because the warehouse admin should calculate directly the amount of physical stocks, occurrence Difference in the number of goods request with the expenditure of goods due to error calculation by Warehouse Admin, takes a long time to make the report of the request and expense of goods thus causing the company's performance to be hampered No Reminder.

\section{References}

[1] Subhan, Mohamad. 2012 Analisa Perancangan Sistem. Jakarta: Lentera IImu Cendekia.

[2] Koo, Yoori. 2016. The Role of Designers in Intergatting Societal Value in The Product and Service Development Processes, Korea: Hongik University, Seoul Republic of Korea. International Jurnal of Design Vol. 10 No.2.

[3] Herawati, Herlin dan Dewi Mulyani.2016. "Pengaruh Kualitas Bahan Baku dan Proses Produksi Terhadap Kualitas Produk Pada UD. Tahu Rosydi Puspan Maron Probolinggo". Universitas Panca Marga Probolinggo: Prosiding Seminar Nasional. ISBN 978-602-60569-2-4.

[4] Susila, Candra Budi dan Ramadhian Agus Triyono. 2015. Sistem Informasi Nilai Mahasiswa Berbasis SMS Gateway Pada Sekolah Tinggi IImu Tarbiyah (STIT) Muhammadiyah Pacitan. Journal Speed-Sentra Penelitian Engineering dan Edukasi. Vol.7, No.3.

[5] Suprayitno dan Uli Indah Wardati. 2012. Pembangunan Sistem Stok Barang Dan Penjualan Pada Toko Sero Elektronik. IJCSS-Indonesian Jurnal on Computer Science Speed. Vol.9, No.3.

[6] Warsito, Ary Budi, Muhamad Yusup, Moh. Iqbal Awi Makaram. (2015). Perancangan Sis+ Menggunakan Metode Yii Framework Pada Perguruan Tinggi Raharja. Jurnal CCIT Vol.8 No.2 - Januari 2015. ISSN : 1978-8282

[7] Mulyani, S. 2016. Metode Analisis dan Perancangan Sistem. Bandung: Abdi Sistematika

[8] Sudarsono, B., \& Erniyati, E. (2017). Perancangan Program Sistem Informasi Persediaan dan Penjualan Barang Pada Toko Sparepart Motor. Simnasiptek 2017, 1(1), 35-39.

[9] Dexter, P. R., Perkins, S., Overhage, J. M., Maharry, K., Kohler, R. B., \& McDonald, C. J. (2001). A computerized reminder system to increase the use of preventive care for hospitalized patients. New England Journal of Medicine, 345(13), 965-970.

[10] Fachruddin, F., \& Jusia, P. A. (2017). PERANCANGAN APLIKASI PERPUSTAKAAN BERBASIS SMS GATEWAY (STUDI KASUS: SMA NEGERI 2 KOTA JAMBI). Jurnal Processor, 9(1), 108-118. 
[11] Dewi, F. K. S., Indriasari, T. D., \& Prayogo, Y. (2016). Rancang Bangun Aplikasi Pengingat Kegiatan Akademik Berbasis Mobile. Jurnal Buana Informatika, 7(4).

[12] Kosidin, R. N. F. (2016). Pemodelan Aplikasi Mobile Reminder Berbasis Android. In Seminar Nasional Teknologi informasi dan Komunikasi.

[13] Wati, D. A. R., \& Rochman, Y. A. (2013). Model Penjadwalan Matakuliah Secara Otomatis Berbasis Algoritma Particle Swarm Optimization (PSO). Jurnal Rekayasa Sistem Industri, 2(1), 22-31.

[14] Kamil, H. (2013). Pengembangan Aplikasi Distribusi Surat Di Fakultas Teknologi Informasi Dengan Notifikasi SMS Menggunakan Framework YII dan GAMMU. Jurnal Nasional Teknik Elektro, 2(2), 39-45.

[15] No, J. K. S. (2015). Applying Performance Dashboard in Hospitals. International Journal Of Software Engineering and Its Applications, 9(1), 213-220.

[16] Clor-Proell, S., Guggenmos, R., \& Rennekamp, K. M. (2018). Mobile Devices and Investment Apps: The Effects of Push Notification, Information Release, and the Fear of Missing Out.

[17] Mulyandi, R., \& Dini, C. A. W. (2014). Aplikasi Absensi Pegawai Kecamatan Batuceper Tangerang Dalam Meningkatkan Akurasi Informasi. CCIT Journal, 7(2), 269-279.

[18] Roihan, A., Sunarya, P. A., \& Wijaya, C. (2018, August). Auto Tee Prototype as Tee Golf Automation in Golf Simulator Studio. In 2018 6th International Conference on Cyber and IT Service Management (CITSM) (pp. 1-5). IEEE. 